\title{
Ikke bare en uskyldig barnesykdom
}

\author{
Vannkopper er som oftest en mild og ufarlig sykdom, og de fleste barn blir friske av seg selv etter omtrent en \\ uke. Men under dårligere hygieniske forhold enn i vår tid og vår del av verden kan den ha et alvorligere forløp. \\ I nr. 13/1933 beskrives et slikt tilfelle (Tidsskr Nor Lægeforen 1933; 53: 690-3).
}

\section{Et tilfelle av gangrenøse vannkopper.}

\author{
Av Alf P. Jacobsen, Oslo.
}

Heldigvis hører det til sjeldenhetene at vannkopper tar et alvorlig forløp og ender med døden. Den farligste komplikasjonen i så henseende er gangrenet. I Zieler Jacobis «Lehrbuch der Haut- und Geschlechtskrankheiten» gjøres der opmerksom på at denne komplikasjon især sees hos voksne, mens den almindelige anskuelse ellers går ut på at varicelle-gangrenet fortrinsvis forekommer hos debile og kakektiske. Jeg har imidlertid hatt anledning til å følge et tilfelle av gangrenøse vannkopper hos et 5 måneder gammelt barn i godt hold. Kanskje har kasus krav på interesse.

Det dreier sig om en 5 måneder gammel, tidligere frisk pike i godt hold - eller rettere sagt i for godt hold. Hun veiet nemlig vel $9 \mathrm{~kg}$, det vil si ca. $2 \mathrm{~kg}$ over middelvekten svarende til alderen. Barnet, som er født i rett tid, har hele tiden fått brystmelk ; men moren har ment at barnet har fått for lite herav, og gitt henne kumelkblanding som tillegg. Annen næring hadde barnet ikke fått.

I den delen av bygden hvor familien bodde, hadde der i den senere tid optrådt flere tilfeller av vannkopper. Foreldrene stillet derfor selv diagnosen hos sin lille pike og tilkalte læge først 6 dager efter utbruddet fordi «utslettet så så stygt ut».

4. januar. Barnet er i godt hold. Tar gjerne brystet. Tp. $=38,5^{\circ}$. P. $=$ kraftig. Ved den almindelige undersøkelse kunde intet patologisk påvises, bortsett fra feberen $o g$

E k s a n t e m e t: På ekstremitetene, abdomem, bryst, rygg og i ansiktet sees et polymorft eksantem, bestående av makler, papler, vesikler og pustler, samt særlig på abdomen og underekstremitetene inntørrede brune kruster. Der var ikke noget påviselig ødem i huden mellem effloresensene, men enkelte av disse, særlig de krustøse, var omgitt av en sterkt betendt rød halo. Dette siste var det eneste som adskilte dette eksantem fra de varicelle-eksantemer jeg hadde hatt anledning til å følge hos barn fra andre gårder i bygden. $\mathrm{Og}$ da patintens mor, av sig selv, oplyste mig om at der siden det første utbrudd stadig var kommet nye, blev diagnosen stillet: Varicellae.

Terapi. Borvannsomslag. Innskrenking av kumelken i næringen. Tillegg av appelsiner, tran og maltekstrakt.

11. januar. Barnet er i godt hold. Har spist bra. Det følger godt med $\mathrm{i}$ alt som foregår.

Eksantemet: Der er fremdeles utbrudd av nye effloresenser, især på øvre del av brystet og halsen. De krustøse effloresenser på abdomen og underekstremiteter er tiltatt betydelig i størrelse ; de er nu ca. ettørestore. Skorpene er blitt sorte og faste. Den røde halo er nu ikke lenger så fremtredende, fordi huden mellem effloresensene er blitt sterkt ødematøs og betendelsesaktig. Enhver berøring av barnets hud på nedre del av kroppen bringer barnet til å skrike ; likeså forsøk på passivt å bevege dets underekstremiteter. Barnet ligger derfor uten å røre sine underekstremiteter. Av denne grunn og fordi det fra før fete barn nu har fătt det betydelige ødem $\mathrm{i}$ huden, blir hudfoldene dype - og viser sig å være sete for et intertriginøst eksem.

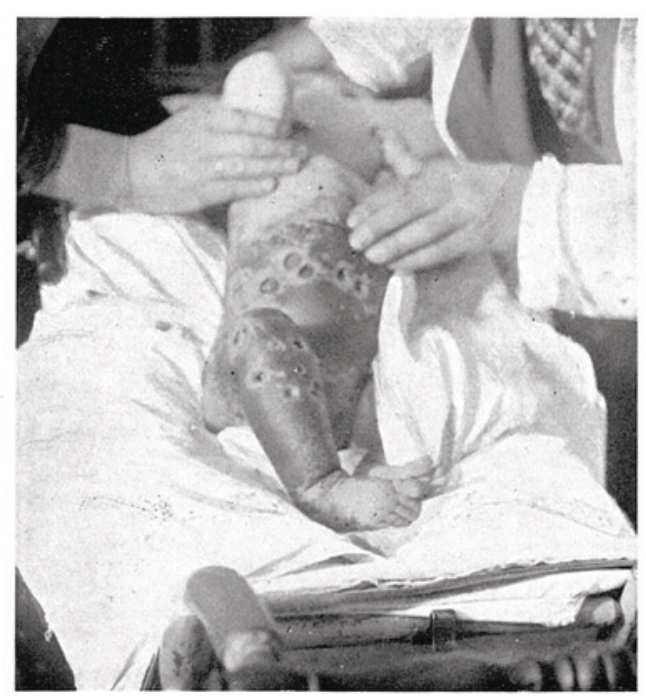

Terapi: Lapisomslag. 1 pct. ung. hydrarg. flav. i hudfoldene og nedentil.

17. januar: Barnet har skreket meget i de siste dager. Ingen avføring på 4 dager, uaktet barnet den hele tid har tatt brystet. Tp. $39^{\circ} \mathrm{C}$.

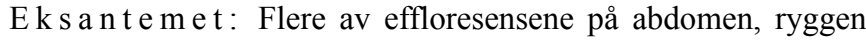
og benene er nu optil 5-øre store, og dekket av en sort skorpe. Denne lar sig lett løsne langs kantene, hvoretter en del tyntflytende, stinkende puss kan klemmes ut. man ser hvorledes skorpen tappformig sitter i et dypt hull i huden, hvis rande er sterkt svulne og hyperemiske. Huden er sterkt ødematøs på underkroppen. Fluktuasjon kan ikke påvises.

Te r a p i : Klyster, hvorefter avføringen atter kom i gang.

25. januar: Barnet ser bare ubetydelig medtatt ut, men skriker hvis man tar i det eller forandrer dets stilling. Tp. $39,3^{\circ}$. Det har nu dannet sig en fluktuerende tumor i den venstre lyske.

Eksantemet: På de store gangrenøse effloresenser er nu krustene falt av, og de 1-5 øre store s å r ligger i dagen (se fotografiet). Sårbunnen har renset sig på flere av dem helt ned til fascien. Sårrandene er steile, svulne og hyperemiske. Ved å klemme barnets toraks og abdomen sammen fra side til annen kan store mengder puss (sølvmateriale?) trykkes ut av hullene på for- og baksiden.

Terapi: Incisjon av tumor i lysken. Det blev uttømt ca. $200 \mathrm{~cm}^{3}$ tyntflytende puss. Neste dag var tp. sunket til $37^{\circ}$, men begynte så i de følgende dager å stige - og holdt sig mellem $39^{\circ} \mathrm{og}$ $40^{\circ}$ inntil mors inntrådte 4 . februar.

Fotografiene er tatt 2. februar. Underkroppens mørke farve skyldes brukes av lapiomslag. 